\title{
Economics
}

2015; 4(6): 125-131

Published online December 18, 2015 (http://www.sciencepublishinggroup.com/j/eco)

doi: 10.11648/j.eco.20150406.15

\section{Testing Causality and Cointegration Between Saving and Investment in Bangladesh}

\author{
Zubaidur Rahman ${ }^{1}$, Md. Elias Hossain ${ }^{2}$ \\ ${ }^{1}$ Department of Economics, Bangabandhu Sheikh Mujibur Rahman Science and Technology University, Gopalganj, Bangladesh \\ ${ }^{2}$ Department of Economics, University of Rajshahi, Rajshahi, Bangladesh
}

Email address:

zubaidur.eco@bsmrsu.edu.bd (Z. Rahman), eliaseco@ru.ac.bd (Md. E. Hossain)

To cite this article:

Zubaidur Rahman, Md. Elias Hossain. Testing Causality and Cointegration Between Saving and Investment in Bangladesh. Economics. Vol. 4, No. 6, 2015, pp. 125-131. doi: 10.11648/j.eco.20150406.15

\begin{abstract}
Interaction between saving and investment has been a major concern to the economists and there exists substantial debate over the nature of long run relationship between them. Thus, the main objective of this paper is to examine the dynamic linkages between saving and investment in Bangladesh using annual time series data covering the period from 1980 to 2014. The stationarity of the data is examined by using the Augmented Dickey-Fuller (ADF) and Phillips-Perron (PP) unit root tests. This paper applied the Johansen-Juselius cointegration test to examine the long run relationship between saving and investment. In order to show the direction of causal relationship between saving and investment, the widely used Granger causality test has been used. The unit root tests revealed that both saving and investment are non-stationary at level forms and they become stationary after taking their first difference. The Johansen-Juselius cointegration analysis suggests that, there exists a long run relationship between saving and investment as it is confirmed by both the Trace and Maximum Eigen-value test statistics. Results found from the Granger causality test suggests that unidirectional causality running from saving to investment existed in Bangladesh over the sample period for a lag length of two periods. Based on the results, pursuance of policy measures towards mobilizing domestic saving is recommended.
\end{abstract}

Keywords: Saving, Investment, Cointegration, Causality, Bangladesh

\section{Introduction}

Saving and investment are considered as important factors in achieving macroeconomic goals of an economy such as maintaining price stability, promoting employment opportunities and thereby contributing to economic growth. The relationship between saving and investment provides important insights into the process of economic development. The basic argument behind this view is that, economic growth critically depends on capital accumulation and capital accumulation stems from investment which depends on saving from domestic and foreign sources. Hence, an increase in saving leads to higher economic growth through capital formation. According to the Solow model, if a nation devotes a large fraction of its income to saving and investment, it will have a high steady-state capital stock and high level of income.

The interaction between saving and investment has been a subject of interest among the economists, and has been an issue of debate as to whether saving causes investment or gets caused by investment.

A study carried out by Feldstein and Horioka (1980) in the context of the OECD countries for the period of 1960 to 1974 found high correlation between domestic saving and domestic investment. They concluded that the degree of international capital mobility among the OECD countries is low. Besides, in case of perfect international capital mobility, they found no relationship between saving and investment. In addition, several empirical studies have been conducted over the past few decades that can be divided into two categories. The first group of literature focused in favour of Feldstein and Horioka framework and explained international capital mobility across different exchange rate and capital control regimes. Feldstein (1983) and Vos (1988) found a close relationship between saving and investment which implies that international capital mobility is imperfect.

Miller (1988) conducted his study on the relationship between saving and investment in the United States applying the cointegration technique and found that saving and investment are cointegrated under the fixed exchange rate 
regime while the same are not cointegrated under the flexible exchange rate regime. A study conducted by De Vita and Abbott (2002) found that saving and investment are cointegrated and they indicated that capital mobility is lower during the fixed exchange rate regime but it is higher during the floating exchange rate regime. Second group of literature has challenged the Feldstein and Horioka framework by arguing that the strong co-movement between saving and investment is explained by other macroeconomic factors such as population growth, productivity shocks, country size and level of income (Tang and Lean, 2008).

Apart from this view, there is another debate among the economists on the direction of influence on each other and it revolves around two issues. The first group of studies relates to whether domestic investment results in domestic saving, and the second relates to how domestic investment affects saving. To answer these issues, a growing body of literature has emerged both at the theoretical and empirical levels and mixed results are found by the researchers. Some researchers found investment to be caused by saving while others found opposite feedbacks (Esso and Keho, 2010; Cooray and Sinha, 2005; Afzal, 2007). Moreover, some studies also found interactive relationship between saving and investment (Chakrabarty, 2006). The vicious circle of poverty given by Ragner Nurkse (1960) postulates that, low investment is caused by low saving. The classical theory also argued that, an increase in saving leads to a reduction in the interest rate, which in turn leads to an increase in investment. Contrarily, Keynes argued that an increase in investment leads to an increase in output and income which, in turn, increases saving (Ramakrishna and Rao, 2012).

Long run relationship between saving and investment has important policy implication for Bangladesh. Research studies examining such relationship in case of Bangladesh using longer data series are very few. This paper tries to fill this gap in the literature and aims to study the long run causal links between saving and investment in Bangladesh using longer period data series.

The rest of the paper is structured as follows: after introducing the issues in the first section, theoretical analysis is presented in Section 2. A brief review of literature is addressed in Section 3. In Section 4, the methodology is presented. Relevant data are presented in Section 5. In Section 6, evaluation of the results is provided. Finally, Section 7 noted some concluding remarks.

\section{Theoretical Underpinning of Saving - Investment Relationship}

Classical economists were of the view that saving and investment are always equal in a fully employed economy, and whenever inequality is arisen between saving and investment, it is brought to equality through a flexible rate of interest. However, according to Keynesian view, the equality between saving and investment is brought about not through the mechanism of rate of interest but through the changes in income. Contrary to the classical view that saving and investment are equal under condition of full employment equilibrium, the Keynesians are of the view that equality between saving and investment can take place below or above the level of full employment.

Keynes has put forward two views on saving-investment equality viz., accounting or definitional equality and functional equality. Actual saving and actual investment are always and necessarily equal at any level of income for the community as a whole and in order to prove it, he defined saving in the current period as the excess of income over expenditure. As regards investment, it is the value of current output of capital goods together with the value of any addition to work in progress or the stock of finished goods. Investment is equal to the output of the community minus consumption.

According to the second version of Keynes, saving is equal to investment at the equilibrium level of income. It is brought about by the adjusting mechanism of income compared to the classical view of variations in the rate of interest. Keynes established equality between saving and investment by defining income as equal to current consumption plus current investment. The basic idea of explaining equality between saving and investment is that it is brought about by changes in income and not through the mechanism of interest rate.

According to the functional equality version, when people save more than what the investors think it worthwhile to invest, the demand for consumer and producer goods falls down. When the goods produced are not profitably sold, the entrepreneurs curtail production of goods and national income falls. If investment is more than saving, then national income rises. The process of changes in income, saving and investment continues till saving and investment are in equilibrium.

\section{Literature Review}

Following the pioneering work of Feldstein and Horioka (1980), the causal relationship between saving and investment has been widely researched which resulted in substantial empirical debate. The empirical studies have focused on investigating the existence of saving-investment relationship, used different approaches of time series econometrics, and have come up with differing results regarding the long run relationship between saving and investment. Moreover, the studies were conducted both in single country contexts as well as in the context of group of countries.

There are several studies which found positive long run relationship between saving and investment in the context of different countries. Chakrabarty (2006) studied the long run relationship between saving and investment in the context of both the OECD and non-OECD countries. Using the multivariate heterogeneous panel cointegration analysis, the study found significant robust positive relationship between ratio of gross domestic investment to GDP and the ratio of gross domestic saving to GDP in both type of countries. 
Nasiru and Usman (2013) explored the relationship between saving and investment in Nigeria for the period 1980-2011 using autoregressive distributed lag (ARDL) bounds testing approach with error correction model (ECM) and found long run relationship between saving and investment. Ang (2010) examined the cointegrating relationship between domestic saving and investment in an ARDL framework using the Malaysian data for the period 1965 to 2003 and found a fairly robust long-run relationship between domestic saving and investment, after controlling the effects of the Asian financial crisis on domestic investment rate. The research study conducted by Sanjib and Joice (2012) investigated the relationship between saving and investment in three diverse economies, namely, US, UK and China. They found a cointegrated relationship between saving and investment in these countries. The findings of a robust long-run cointegrated relationship between domestic saving and investment in these studies suggest that change in domestic saving is closely associated with change in investment in the long run.

Some studies suggest that there is no such long run relationship between saving and investment. Wet and Eyden (2005) concluded that rate of investment in the Sub-Saharan African countries is not determined by domestic saving, rather it is determined by foreign aid and FDI flows into these countries. Ramakrishna and Rao (2012) conducted a research on the relationship between saving and investment in Ethiopia. They found that there is no long-run relation between saving and investment in Ethiopia. Cooray and Sinha (2005) conducted a research on saving and investment in twenty African countries and found that long run relationship does not exist in eighteen out of those twenty countries. Studies by Cyrille (2010) on fifteen Sub Saharan African countries and Wahid et al., (2004) on the five South Asian countries observed that there is low correlation between saving and investment in the sample countries.

There are some studies which observed mixed findings regarding the long run relationship between saving and investment. The study by Esso and Keho (2010) conducted on the UEMOA member countries showed that domestic saving plays an active role in financing investment in only three countries. For the other four countries, the two variables are not related. Onafowara et al. (2011) studied the relationship between saving and investment in eight advanced economies of the European Union and found statistically significant evidence of cointegration for six countries. Afzal (2007) studied causality between saving and investment in the case of developing countries using conventional and time series econometric techniques. The study found no long-run relationship between saving and investment in seven countries of the sample while found bidirectional causality between saving and investment in South Africa and unidirectional causality from saving to investment in Pakistan and Sri Lanka.

There are substantial differences among the previous literature in terms of using econometric tools. Some literature used cointegration technique and Granger causality test to justify the relationship between saving and investment (Ramakrishna and Rao, 2012; Narayan, 2006; Chakrabarty, 2006; Afzal, 2007) while others (Esso et al., 2010; Onafowara, 2011; Ang, 2010; Nasiru and Usman, 2013) applied autoregressive distributed lag (ARDL) bounds testing approach and error correction model (ECM) methods to clarify the relationship between saving and investment. In terms of using data, the previous literatures are also differed from each other. As for example, Wahid et al. (2004), Esso et al. (2010), Onafowara (2011), Cooray and Sinha (2005) used panel data or cross country data to test the relationship between saving and investment, while Ramakrishna and Rao (2012), Narayan (2006), Nasiru and Usman (2013) used single country time series data to conceptualize the relationship between saving and investment. Studies also differed in terms of the results obtained. Some studies found uni-directional relationship between saving and investment (Narayan, 2006) while others found bi-directional relationship between saving and investment (Afzal, 2007). Alternatively, some studies found no causal relationship between saving and investment (Ramakrishna and Rao, 2012) and others showed mixed results (Afzal, 2007).

Majority of the previous studies observed the relationship between saving and investment mostly in the context of panel data or cross country data. In these studies, long length of time period was ignored which carry significant implication for policy purposes than simply using of cross country or panel data of short length. In this context, the present study is an improvement over the past studies. Moreover, this study has taken the case of Bangladesh in investigating the long run relationship between saving and investment, a developing economy which received less attention by the researchers.

\section{Empirical Methodology}

The empirical methodology of this paper is based on time series econometrics and is comprised of three steps. In the first step, time series properties of the data series are investigated by employing the unit root test. In the second step, a test for cointegration is performed to investigate the long run relationship between saving and investment. At last, causality check is carried out using the Granger causality test to observe the direction of causality between the variables (Granger, 1988).

\subsection{Unit Root Test}

Empirical estimation based on time series data assumes that the underlying time series are stationary. If the data series are non-stationary, then they can portray spurious or nonsensical relationship between the variables (Gujariti, 2004). Therefore, ensuring that the data series are stationary is necessary before going for any econometric exercise with the data. In this paper, the stationarity of the data series is investigated using the Augmented Dickey-Fuller (ADF) and Phillips-Perron (PP) unit root tests for both the saving and investment data series. The Augmented Dickey-Fuller test can be done with the help of following equation with a 
constant term:

$$
\Delta\left(\ln Y_{t}\right)=\beta+\delta\left(\ln Y_{t-1}\right)+\sum_{i=1}^{m} \alpha_{i} \Delta \ln Y_{t-i}+u_{t}
$$

Where, $\Delta\left(\ln Y_{t}\right)=\ln Y_{t}-\ln Y_{t-1}$ and $\mathrm{Y}$ is the variable under consideration, $\mathrm{m}$ is the number lags in the dependent variable chosen by the AI criterion, and $\mathrm{u}_{\mathrm{t}}$ is the stochastic error term. Under the ADF test, the null hypothesis of a unit root indicates that the coefficient of the variable, $\ln Y_{t-1}$, in the above equation is zero. The general rule is that, if the null hypothesis is rejected, then the series is stationary and no differencing is needed to bring on stationary in the series. The results of the ADF test has further been verified by the use of the Phillips-Perron test, suggested by Phillips (1987) and extended by Perron (1988), and Phillips and Perron (1988). The Augmented Dicky-Fuller unit root test takes care of possible serial correlation in the error terms by adding the lagged difference terms of the regressand. Phillips-Perron unit root test use nonparametric statistical methods to take care of the serial correlation in the error terms without adding lagged difference terms. The test regression for the PP test is the $\mathrm{AR}(1)$ process, as follows:

$$
\Delta \ln Y_{t}=\alpha+\beta \ln Y_{t-1}+\varepsilon_{t}
$$

In the PP test, based on the estimated $\beta$ coefficient, the test statistic, $\tau_{\beta}$ is calculated and the null hypothesis of containing unit root is rejected if $\tau_{\beta}$ is less than the asymtotic critical value.

\subsection{Cointegration}

Cointegration means that despite being individually nonstationary, a linear combination between two or more time series can be stationary. Cointegration techniques are used to find the long-run relationship between variables if they are integrated of same order. Cointegration of two (or more) time series suggests that there is a long run or equilibrium relationship between them. There are several econometric techniques to investigate the long run relationship among the time series macroeconomic variables. The cointegration technique comprises of univariate cointegration (EngleGranger, 1987) and Fully Modified Ordinary Least Squares (Philips and Hansen, 1990) and multivariate cointegration techniques (Johansen, 1988; Johansen and Juselius, 1990, and Johansen, 1995). The testing hypotheses are the null of non-cointegration against the alternative that is the existence of cointegration by using the maximum likelihood procedure (Johansen and Juselius, 1990). The Johansen approach to cointegration test is based on two test statistics, viz., the Trace test statistic, and the Maximum Eigen value test statistic.

The Trace test statistic can be specified as:

$$
\tau_{\text {trace }}=-T \sum_{i=r+1}^{k} \log \left(1-\lambda_{i}\right)
$$

where, $\lambda_{i}$ is the $i^{\text {th }}$ largest eigen value of matrix $\tau$ and $\mathrm{T}$ is the number of observations. In the Trace test, the null hypothesis assumes that the number of distinct cointegrating vectors is less than or equal to the number of cointegrating relations (r).

The Maximum Eigen value test examines the null hypothesis of exactly $r$ cointegrating relations against the alternative of $r+1$ cointegrating relations with the test statistic:

$$
\tau_{\max }=-T \log \left(1-\lambda_{r+1}\right)
$$

where, $\lambda_{r+1}$ is the $(r+1)^{t h}$ largest squared eigen value.

It is well known that Johansen's cointegration test is very sensitive to the choice of lag length. Akaike Information criterion (AIC) and the Likelihood Ratio (LR) test are used to select the number of lags required in the cointegration test.

\subsection{Granger Causality Test}

If the two variables are cointegrated then it indicates that there exists a long-run relationship between these variables. This long run relationship is further examined by Granger causality test within the bivariate vector autoregressive framework (Granger, 1986). Granger causality test facilitates to identify the direction of causality between the variables if long run relationship exists. The Granger causality test involves the following equations for $\ln S$ and $\ln I$ with the right hand side always consisting of lagged values of the dependent variables:

$$
\begin{aligned}
& \ln S=\sum_{i=1}^{m} \gamma_{i} \ln I_{t-i}+\sum_{j=1}^{m} \psi_{j} \ln S_{t-j}+u_{1 t} \\
& \ln I=\sum_{i=1}^{m^{\prime}} \lambda_{i} \ln I_{t-i}+\sum_{j=1}^{m^{\prime}} \delta_{j} \ln S_{t-j}+u_{2 t}
\end{aligned}
$$

Here focus is given on the terms with $\gamma$ and $\delta$ in the above equations. If the $\gamma_{i}$ coefficients as a set are statistically different from zero, that is, $\sum \gamma_{i} \neq 0$, then it may be concluded that saving depends on past values of investment, and hence changes in saving are caused by changes in investment. The same is applicable to investment causing saving when $\sum \delta_{j} \neq 0$.

\section{Source of Data}

This study is based on secondary data on saving and investment of Bangladesh for the time period 1980-2014. The annual time series data are collected from the World development indicators, 2014 published by the World Bank, International Monetary Fund (IMF) CD-Rom, and from 
various issues published by Bangladesh Bureau of Statistics (BBS). For empirical testing the data were converted into their natural logarithms. Table 1 shows the descriptive statistics of the data.

Table 1. Descriptive Statistics of the Data (\% of GDP).

\begin{tabular}{llllll}
\hline Variables & Mean & Maximum & Minimum & $\begin{array}{l}\text { Standard } \\
\text { Deviation }\end{array}$ & Variance \\
\hline Saving & 19.06 & 30.53 & 5.57 & 8.72 & 76.03 \\
Investment & 21.15 & 28.97 & 14.69 & 4.30 & 18.49 \\
\hline
\end{tabular}

Source: Author's own calculation.

It is found from Table 1 that mean value of saving as a percentage of GDP is 19.06 with maximum value of 30.53 and minimum 5.57. The standard deviation and variance of saving are 8.72 and 76.03 , respectively. On the other hand, the mean value of investment expressed as a percentage of GDP is 21.15 with a standard deviation of 4.30 and variance of 18.49. It indicates that variation in the distribution of saving is more than that of investment.

Figure 1 presents the time series plots of saving and investment as a percentage of GDP in Bangladesh from 1980 to 2014. As shown in Figure 1, it is evident that, the share of saving as a percentage of GDP rose from a low of $5.56 \%$ in 1980 to a high of $29.01 \%$ in 2014. Gross domestic investment is primarily funded by domestic saving which includes household saving, corporate saving and government saving. It increased from $14.69 \%$ of GDP to $28.97 \%$ of GDP during the same period. Figure 1 also shows that saving and investment exhibit an upward trend and having a tendency to walk together, implying that they are likely to be causally linked to each other.

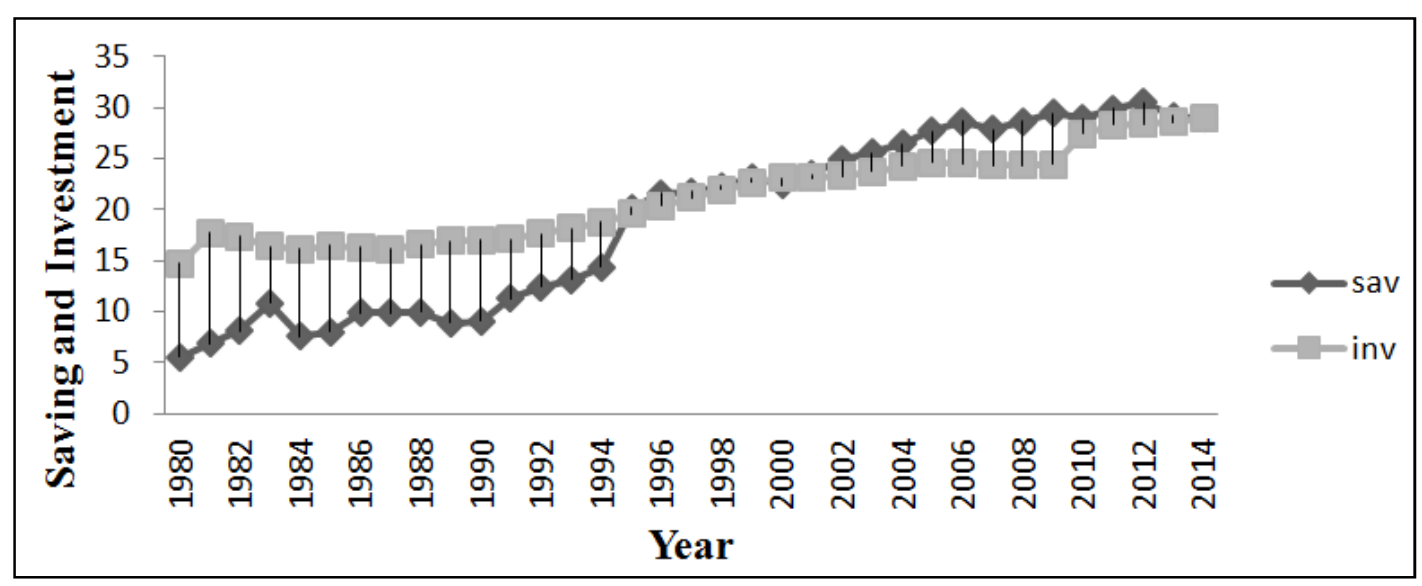

Figure 1. Saving and Investment in Bangladesh (1980-2014).

\section{Empirical Results}

\subsection{Augmented Dickey-Fuller Test}

Results of the Agmented Dickey Fuller test are presented in Table 2. It is seen from the table that both $\ln I$ and $\ln S$ series are nonstationary at their level form as confirmed by the absolute calculated values of ADF test which are smaller than the MacKinnon asymptotic-critical values. However, both $\ln I$ and $\ln S$ become stationary after taking their first difference.

\subsection{Phillips-Perron Test}

Similarly, results of the Pillips-Perron (PP) unit root test are shown in Table 3. It indicates that both the data series- $\ln I$ and $\ln S$ are non-stationary at their level forms. However, both series become stationary at $1 \%$ level of significance. after taking their first difference.

Table 2. Results of ADF Unit root Test.

\begin{tabular}{|c|c|c|c|c|c|c|}
\hline \multirow[b]{2}{*}{ Variable } & \multicolumn{3}{|c|}{ ADF (without intercept) } & \multicolumn{3}{|c|}{ ADF (with intercept) } \\
\hline & Level & First Difference & Critical Values & Level & First Difference & Critical Values \\
\hline $\ln I$ & 0.01 & $-6.21 * * *$ & $-3.64(1 \%)$ & -3.89 & $-6.67 * * *$ & $-4.25(1 \%)$ \\
\hline $\ln S$ & 1.07 & $-5.36^{* * *}$ & $\begin{array}{l}-2.95(5 \%) \\
-2.61(10 \%)\end{array}$ & -1.42 & $-5.34 * * *$ & $\begin{array}{l}-3.54(5 \%) \\
-3.21(10 \%)\end{array}$ \\
\hline
\end{tabular}

Note: $* * * * *$ and $*$ denote the rejection of null hypothesis of unit root at $1 \%, 5 \%$ and $10 \%$ level of significance.

Table 3. Results of Pillips-Perron Test.

\begin{tabular}{|c|c|c|c|c|c|c|}
\hline \multirow[b]{2}{*}{ Variable } & \multicolumn{3}{|c|}{ PP(without intercept) } & \multicolumn{3}{|c|}{ PP (with intercept) } \\
\hline & Level & First Difference & Critical Values & Level & First Difference & Critical Values \\
\hline $\ln S$ & 1.07 & $-5.36 * * *$ & $-3.63(1 \%)$ & -1.51 & $-5.34 * * *$ & $-4.25(1 \%)$ \\
\hline $\ln I$ & -0.18 & $-6.21 * * *$ & $\begin{array}{l}-2.95(5 \%) \\
-2.61(10 \%)\end{array}$ & -1.99 & $-6.63 * *$ & $\begin{array}{l}-3.54(5 \%) \\
-3.21(10 \%)\end{array}$ \\
\hline
\end{tabular}

Note: $* * * * *$ and $*$ denote the rejection of null hypothesis of unit root at $1 \%, 5 \%$ and $10 \%$ level of significance. 
Table 4. Results of Johnsonsen Cointegrating Test.

\begin{tabular}{|c|c|c|c|c|c|c|}
\hline \multirow{2}{*}{$\begin{array}{l}\text { No. of conintegrating } \\
\text { equations (r) }\end{array}$} & \multicolumn{3}{|l|}{ Trace Test } & \multicolumn{3}{|c|}{ Maximum Eigen value test } \\
\hline & Test statistic & $1 \%$ critical value & $5 \%$ critical value & Test statistic & $1 \%$ critical value & $5 \%$ critical value \\
\hline None* & 19.51 & 23.46 & 18.17 & 17.12 & 21.47 & 16.87 \\
\hline At most one & 2.38 & 6.40 & 3.74 & 2.38 & 6.40 & 3.74 \\
\hline
\end{tabular}

Table 5. Results of Granger Causality Test.

\begin{tabular}{|c|c|c|c|c|c|}
\hline Null hypothesis & Lags & Observation & F-statistics & Probability & Result \\
\hline $\begin{array}{l}\ln S \text { does not Granger cause } \ln I \\
\ln I \text { does not Granger cause } \ln S\end{array}$ & 2 & 34 & $\begin{array}{l}5.54608 \\
0.96966\end{array}$ & $\begin{array}{l}0.00935 \\
0.39158\end{array}$ & $\mathrm{~S} \Rightarrow \mathrm{I}$ \\
\hline
\end{tabular}

\subsection{Results of Cointegration Test}

Results of Johnsen's Trace test and Maximum Eigen value test assuming quadratic deterministic trends in data with intercept are provided in the Table 4. The optimum lag length is determined by using the Akaike information criterion. It is found from Table 4 that both the maximum eigen value and trace statistics reject the null hypotheses, $r=0$ at $5 \%$ significance level as the test statistics exceeded critical values in both cases.

Therefore, it can be concluded that, there is a long run relationship between saving and investment in Bangladesh as it is confirmed by both the Trace and Maximum Eigen value test statistics.

\subsection{Granger Causality Test}

Granger proposed that two variables can be used to predict each other if they have causal link. Since the order of integration of saving and investment is one, Granger Causality test is conducted on the first differenced values of saving and investment.

Result of the Granger causality test is shown in Table 5 and it is shown that the hypothesis "InS does not Granger cause InI" is rejected as the estimated F-value is statistically significant. On the other hand, the hypothesis "InI does not Granger cause InS", is not rejected because the estimated F-value is statistically insignificant. The implication of Granger causality test infers that unidirectional causality running from saving to investment existed in Bangladesh during the sample period.

\section{Conclusion and Policy Suggestions}

This study applies annual time series data to identify the causal relationship between saving and investment in Bangladesh covering the period from 1980 to 2014. The Augmented Dickey-Fuller and Phillips-Perron tests were used to check the stationarity of saving and investment data series. Results obtained from both the tests indicate that saving and investment are nonstationary but both become stationary after taking their first difference. Cointegration analysis performed by Trace test and Maximum Eigen value test suggests that there is a long run relationship between saving and investment in Bangladesh. Again, the Granger causality test indicates a unidirectional relationship between saving and investment running from saving to investment in Bangladesh. Based on the findings, the following policy recommendations can be suggested:

i). Government should given priority to increase saving from both domestic and external sources.

ii). Government should increase investment in productive sectors through capital accumulation and reduce its unnecessary expenditures so that saving can be further increased.

iii). A significant proportion of domestic saving in Bangladesh is made by households. But the proportion as a percentage of domestic savings is very low. Having relied on foreign saving it is not possible to ensure sustainable economic growth for a country like Bangladesh. In the long-run, Bangladesh has to depend on domestic saving. Therefore, government should take appropriate policies to increase household savings through various incentives.

\section{References}

[1] Afzal, M., (2007). Savings and Investment in Developing Countries: Granger Causality test. Philippine Review of Economics, 44, No.2.

[2] Ang, J. B., (2007). Are saving and investment cointegrated? The Case of Malaysia (1965-2003). Applied Economics, 39, $2167-2174$

[3] Bangladesh Bureau of Statistics (BBS), 1998. Statistical Yearbook of Bangladesh Dhaka: Statistics Division, Ministry of Planning. Government of the Peoples Republic of Bangladesh.

[4] Bangladesh Bureau of Statistics (BBS), 2001. Statistical Yearbook of Bangladesh 2001. Dhaka: Statistics Division, Ministry of Planning. Government of the Peoples Republic of Bangladesh.

[5] Bangladesh Bureau of Statistics (BBS), 2004. Statistical Yearbook of Bangladesh 2004. Dhaka: Statistics Division, Ministry of Planning. Government of the Peoples Republic of Bangladesh.

[6] Bangladesh Bureau of Statistics (BBS), 2006. Statistical Yearbook of Bangladesh 2004. Dhaka: Statistics Division, Ministry of Planning. Government of the Peoples Republic of Bangladesh. 
[7] Bangladesh Bureau of Statistics (BBS), 2007. Statistical Yearbook of Bangladesh 2004. Dhaka: Statistics Division, Ministry of Planning. Government of the Peoples Republic of Bangladesh.

[8] Bangladesh Bureau of Statistics (BBS), 2009. Statistical Yearbook of Bangladesh 2009. Dhaka: Statistics Division, Ministry of Planning. Government of the Peoples Republic of Bangladesh.

[9] Bangladesh Bureau of Statistics (BBS), 2006. Yearbook of Agricultural Statistics of Bangladesh 2006. Dhaka: Statistics Division, Ministry of Planning. Government of the Peoples Republic of Bangladesh.

[10] Bangladesh Bureau of Statistics (BBS), 2010. Yearbook of Agricultural Statistics of Bangladesh 2010. Dhaka: Statistics Division, Ministry of Planning. Government of the Peoples Republic of Bangladesh.

[11] Chakrabarty, A., (2006). The Saving Investment relationship revisited: New Evidence from Multivariate Heterogenous Cointegrating Analyses. Journal of Comparative Economics, 34, 402-419.

[12] Cooray, A. and D. Sinha (2005). The Feldstein-Horioka Model Re-Visited for African Countries. UTAS, School of Economics Discussion Paper, 2005-09.

[13] Cyrille, S. M., (2010). Saving-Investment Correlation and Capital Mobility in Sub-Saharan African Countries: A Reappraisal through Inward and Outward Capital Flows' Correlation. International Journal of Economics and Finance, 2, No. 2.

[14] De Vita, G. and Abbott, A., (2002). Are saving and investment cointegrated? An ARDL bounds testing approach. Economics Letters, 77(2), pp. 293-299.

[15] Engle, R.F. and Granger, C.W.J., (1987). Co-integration and error-correction: Representation, estimation and testing. Econometrica, 55(2), pp. 987-1008.

[16] Esso, L.J. and Keho., (2010). The savings- Investment Relationship: Cointegration and causality Evidence from Uemoa Countries. International Journal of Economics and Finance, 174-181.

[17] Feldstein, M. and Horioka, C., (1980). Domestic saving and international capital flows. Economic Journal, 90, 314-329.

[18] Feldstein, M. (1983). Domestic Saving and International Capital Movements in the long run and the short run. European Economic Review, 21, 129-151.

[19] Government of Bangladesh (2015). Bangladesh Economic Review 2015, Ministry of Finance, Dhaka.

[20] Granger, C. W. J., (1986). Developments in the Study of Cointegrated Economic Variables. Oxford Bulletin, 3, 213-228.

[21] Granger, C.W.J. and Newbold, P. (1974) Spurious Regression in Econometrics. Journal of Econometrics, 2, pp. 111-120.
[22] Gujrati, N. D., (2004). Basic Econometrics, $4^{\text {th }}$ Edition, McGraw-Hill/Irwin.

[23] Johanson, S., (1988). The statistical analysis of cointegration vectors. Journal of. Economic Dynamics and Control 12, pp.231-254.

[24] Johansen, S. and Juselius, K., (1990), Maximum likelihood estimation and inference on cointegration with applications to the demand for money. Oxford Bull. Econ. Stat. 52, 169-210.

[25] Johansen, S. (1995), "Likelihood-based Inference in Cointegrated Vector Autoregressive Models", Oxford: Oxford University Press.

[26] Miller, S.M., (1988). Are saving and investment cointegrated? Economics Letters, 27, 31-34.

[27] Nasiru, N. and Usman, H. M., (2013). The Relationship between Domestic Savings and Investment: The FeldsteinHorioka Test Using Nigerian Data. CBN Journal of Applied Statistics, 4(1), 75-88.

[28] Narayan, P. K. (2005). The Relationship Between Saving and Investment for Japan, Japan and the World Economy, 17, 293 309.

[29] Onafowara, O. A., Owoye, O. and Huart, F., (2011). The Temporal Relationship between Saving and Investment: Evidence from Advanced EU Countries" International Journal of business and Social Science, 2, No. 2.

[30] Phillips, P.C.B., and Perron P., (1988). Time Series Regression with a Unit Root, Biometrica, 75, 335-346.

[31] Phillips, P. C. B and Hansen, B. E. (1990) Statistical inference in instrumental variables regression with $\mathrm{I}(1)$ processes, Review of Economic Studies, 57, 99-125.

[32] Ramakrishna G. and Rao, S.V., (2012). The Long run Relationship between Savings and Investment in Ethiopia: a Cointegration and ECM Approach. Developing country Studies, 2(4).

[33] Vos, R. (1988) Saving, Investment and foreign capital flows: Have capital markets become more integrated? Journal of Development Studies, 24,310-334.

[34] Wet, D. A. and Van Eyden (2005). Capital Mobility in Sub Sub-Saharan Africa: A panel Data Approach. South African Journal of Economics, 73, 1-22

[35] Wahid, A. N. M., Salahuddin, M. and Noman, A. M., (2004). Saving Investment Correlation in South Asia- A Panel Approach. European Journal of Economics, Finance and Administrative Sciences, 11 (2008), 1-7.

[36] World Bank. 2014. World Development Indicators 2007. Washington, DC: World http://devdata.worldbank.org/wdi2007/contents/index2htm. (accessed 20 July, 2015) 